\title{
Profile of a temporomandibular dysfunction and orofacial pain service of a Brazilian public university: what has changed in $\mathbf{1 0}$ years? Retrospective study
}

\author{
Perfil de atendimento de um serviço de disfunção temporomandibular e dor orofacial de uma \\ universidade pública brasileira: o que mudou em 10 anos? Estudo retrospectivo
}

Lais Valencise Magri ${ }^{1}$, Melissa de Oliveira Melchior ${ }^{1}$, Ana Maria Bettoni Rodrigues da Silva ${ }^{1}$, César Bataglion ${ }^{1}$, Marcelo Oliveira Mazzetto ${ }^{1}$, Marco Antonio Moreira Rodrigues da Silva ${ }^{1}$

\section{ABSTRACT}

BACKGROUND AND OBJECTIVES: The search for healthcare services for the treatment of temporomandibular disorders and orofacial pain has increased in the last decades due to the higher access to information and demand for treatment. The objective of this study was to analyze the profile of the service of caring for patients with temporomandibular disorders and orofacial pain of a university service over 10 years.

METHODS: The quantitative data on temporomandibular disorders and orofacial pain care were collected from the School of Dentistry of Ribeirão Preto, from the Sistema de Informatizaçáo de Clínicas Odontológicas da Universidade de São Paulo (ROMEU) for a period of 10 years (2006 to 2016). The data included the total of patients assisted, discharges, absences, referrals to other disciplines, occlusal splints, self-management orientations, speech therapy and physiotherapy, low-intensity laser therapy sessions and electromyography tests. The data were descriptively analyzed. RESULTS: There was an increase in the number of patients assisted over the years, in addition to an increase in discharges and reduction of referrals to other disciplines. There was also increased use of pain education procedures and in the number of speech therapy and physiotherapy provided. The occlusal splints followed the increase in the number of patients assisted.

CONCLUSION: Over 10 years there was an increase in the number of patients assisted, an increasing appreciation of the practices directed at pain education, self-management orientations, and multidisciplinary action. Also, the occlusal splint was shown to be a therapeutic option still widely used in dentistry.

1. Universidade de São Paulo, Faculdade de Odontologia de Ribeirão Preto, Departamento de Odontologia Restauradora, Ribeirão Preto, SP, Brasil.

Submitted in March 06, 2018.

Accepted for publication on June 26, 2018.

Conflict of interests: none - Sponsoring sources: none.

Correspondence to:

Avenida do Café, s/n - Monte Alegre, Faculdade de Odontologia de Ribeirão Preto 14040-904 Ribeirăo Preto, SP, Brasil.

E-mail: mmelchior@forp.usp.br

(c) Sociedade Brasileira para o Estudo da Dor
Keywords: Healthcare services, Orofacial pain, Temporomandibular joint dysfunction syndrome.

\section{RESUMO}

JUSTIFICATIVA E OBJETIVOS: A busca por serviços de atendimento a pacientes com disfunção temporomandibular e dor orofacial tem crescido nas últimas décadas em função do maior acesso à informaçáo e maior demanda por tratamento. $\mathrm{O}$ objetivo deste estudo foi analisar o perfil de atendimento a pacientes com disfunçâo temporomandibular e dor orofacial de um serviço universitário ao longo de 10 anos.

MÉTODOS: Foram coletados dados quantitativos do atendimento de disfunção temporomandibular e dor orofacial da Faculdade de Odontologia de Ribeirão Preto a partir do Sistema de Informatizaçáo de Clínicas Odontológicas da Universidade de São Paulo (ROMEU) relativos a um período de 10 anos (2006 a 2016): total de pacientes atendidos, altas, faltas, encaminhamentos para outras disciplinas, placas oclusais, orientaçóes de automanejo, terapias fonoaudiológica e fisioterapêutica, sessōes de laserterapia de baixa intensidade e exames de eletromiografia. Os dados foram analisados de forma descritiva.

RESULTADOS: Houve um aumento no número de pacientes atendidos ao longo dos anos, além de um aumento das altas e redução de encaminhamentos para outras disciplinas. Foi também verificado um aumento crescente dos procedimentos de educação em dor e do número de atendimentos fonoaudiológicos e fisioterapêuticos. As placas oclusais acompanharam o aumento de atendimentos.

CONCLUSÁO: Ao longo de 10 anos houve um aumento de atendimentos, uma crescente valorização de práticas voltadas para educação em dor, orientaçóes de automanuseio e atuação multidisciplinar, além disso a placa oclusal se mostrou uma opção terapêutica ainda bastante utilizada na odontologia.

Descritores: Dor orofacial, Serviços de saúde, Síndrome da disfunção da articulação temporomandibular.

\section{INTRODUCTION}

The term temporomandibular disorder (TMD) represents a heterogeneous set of musculoskeletal alterations of which its most common subtypes include painful disorders, such as myofascial 
pain and arthralgia, internal derangements, and degenerative disorders of the temporomandibular joints (TMJ). The medical condition also considers the impact of chronic pain on the person's life, relating the psychological factors, such as depression, and the psychosocial ones, as damages in the daily life activities and tendency to drugs abuse ${ }^{1}$.

The "cause-effect" relation with the TMD is yet to be learned, but the predisposing and maintenance factors, as well as the worsening and improvement factors, are already known. For each patient, the different factors are like the pieces of a jigsaw puzzle that when you manage to assemble it, often with the contribution of complementary tests, you can find the diagnosis, thus allowing the choice of the related treatment modalities. Formerly, the diagnosis hypotheses were primarily based on biomechanical aspects that involved the relationship between dental occlusion and the anatomical and physiological position of the $\mathrm{TMJ}^{2,3}$. Consequently, the treatments were proposed aiming the decrease of the occlusal impact on the TMJ's functioning and the related structures since it was believed that this was the main "remedy" for the painful TMD ${ }^{4}$.

There is currently a consensus that the conservative and reversible treatments are the best choice in the first instance since the painful TMD is a clinical condition with fluctuation characteristics and spontaneous remission of signs and symptoms. Within this perspective, therapeutic modalities such as interocclusal stabilization splint, mandibular exercises, physiotherapy, pharmacological therapy, orofacial myofunctional therapy, pain education, and self-handling guidance are effective choices in the reduction of the painful symptom and mandibular mobility improvement, with proven scientific evidence 5 .

When considering the presence of different factors associated to the TMD, the TMJ Occlusion and Disorders Service (SODAT), a place that gathers data for this research, integrates the connection of education and research with the society, encompassing multi-professional areas such as dentistry, speech therapy, physiotherapy, psychology, among others.

The investigation of the public services attendance towards the TMD and orofacial pain (OP) area has been gaining importance over the last years due to a high incidence in the population, besides the impact on the life quality and expenses related to lost workdays and the treatment for these patients ${ }^{6}$. Also, the evaluation of these services targeted on handling the OPs significantly contributes to a better understanding of the epidemiological characteristics and for the planning of teaching and care strategies aimed at higher effectiveness in the control of the signs and symptoms $s^{6-8}$.

The purpose of this study was to demonstrate the attendance profile of TMD and OP patients of a university service throughout ten years to understand the changes in the practice of care according to a historical series.

\section{METHODS}

Retrospective, longitudinal, descriptive study. The quantitative data was collected from the Dental Clinics Computerization System of the University of São Paulo (ROMEU) regarding a 10-year period (2006-2016). The procedures performed in the undergraduate, graduate, and extension practices are systematically entered ROMEU in order to allow the evaluation and the health actions planning.

The data analyzed in this study was computed per year to verify trends of the service during the ten years evaluated. The absolute data related to the following were collected:

- Total number of first consultations, which represents the patients' access to the service; each patient, with a specific medical history, was computed only once a year, that is, only the first consultation was accounted for and not the return visits. Besides, throughout the years, while the patients attended the service, they were not accounted for as new patients, since the purpose of this analysis was to verify the Primary Care patients' access to this secondary care service;

- Missed appointments, i.e., the absences with or without justification for the return visit days, which represents the service attendance;

- Total and partial discharges, which refer to the completion of the treatment and represent the resolving capacity of the cases through this service;

- Referral to other disciplines that may have occurred in different times of the treatment, in the beginning, when the patient's need for care was not compatible with the purpose of the service that suggests an inappropriate referral from the dental surgeon of the Primary Care. Also, during and after the treatment, which indicates a complementary need for dental care and related areas; - Number of interocclusal stabilization splint made throughout the year;

- Self-handling guidance, which represents home care strategies performed by the own patient with the purpose of learning, changing the behavior, and relief of the painful condition;

- Physiotherapy sessions, including the low-level laser therapy application procedures, transcutaneous electrical nerve stimulation (TENS), ultrasound, and manual therapies;

- Speech therapy sessions that included the orofacial myofunctional therapy procedures;

- Surface electromyography examinations of the masseter and anterior temporal muscles with the purpose of complementing the muscular assessment in research protocols developed by this teaching institution.

The choice of the analyzed variables aimed at including the purpose of analyzing the TMD and OP service profile, in accordance with the information provided in the computerized system used in this teaching and care institution. It is worth noting that this study did not use the information included in the patient's medical history; therefore, the detailed information was not analyzed, such as the types of diagnosis found.

\section{Statistical analysis}

The quantitative character data, collected from the "ROMEU" computerized system, was organized in Excel spreadsheets as absolute variables, year by year (2006-2016). The descriptive analysis of the data was performed through the count according to the categories of procedures already described. From the result of this data compilation, scatter plots were elaborated for the analysis of the historical series in each procedure category. 


\section{RESULTS}

Throughout the ten years that were evaluated, it is possible to observe an increase in the total number of registrations of patient's access to the service (total of first consultations), primarily as of 2012, with a continuous growth up to 2016. The number of discharges has also increased over time, data that is compatible with the rise in the total of first consultations. Yet, the number of absences, despite representing a slight escalation as of 2011, did not present such evident growth as the data previously described. Inversely to the others, the number of referrals to other disciplines has gradually decreased in the assessed years (Figure 1).

Regarding the treatment modalities, an increase of registrations for the interocclusal stabilization splint installation was observed, becoming more evident as of 2012 and at its maximum values in 2016 . Likewise, the self-handling guidance has equally shown a constant increase in this analyzed historical series, with this growth starting in 2010 and maximum values also in 2016 (Figure 2).

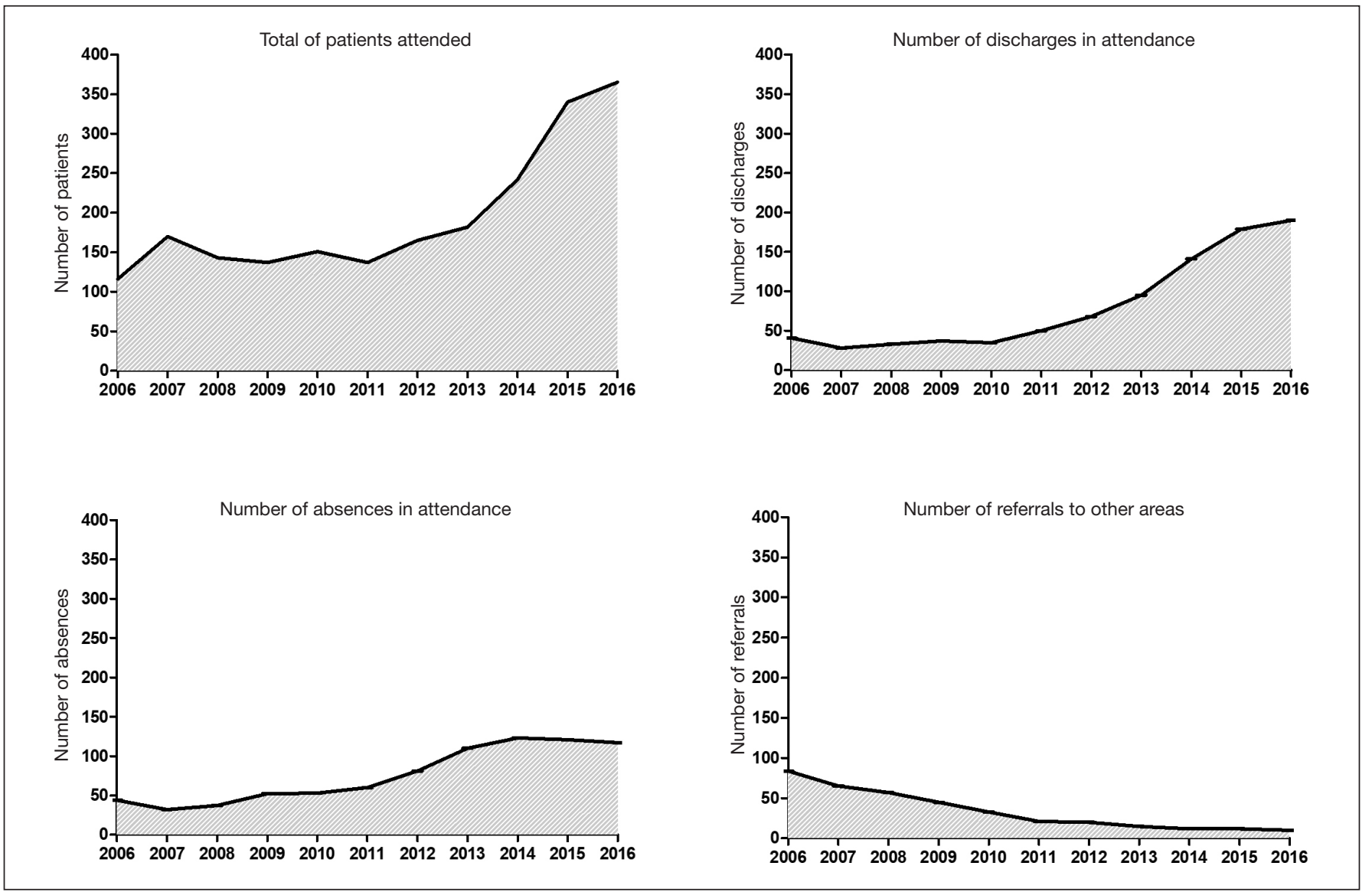

Figure 1. Total of first consultations, the absence of patients in services, number of discharges from the treatment, and referral to other disciplines throughout the ten evaluated years

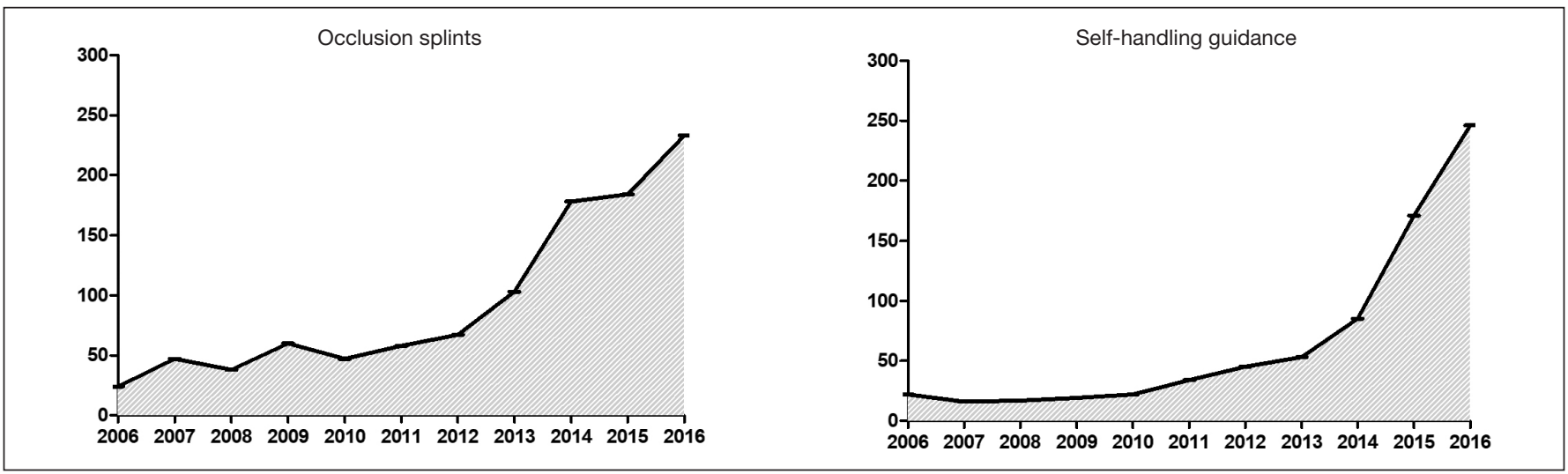

Figure 2. Total number of interocclusal stabilization splints and self-handling guidance over the ten evaluated years 
The number of attendances regarding the speech therapy and physiotherapy sessions has fluctuated throughout the years due to the variation in the availability of the professionals in the area of the service, which happens at a dental school. The surface electromyography examinations have also fluctuated over time due to the occurrence of researches involving this complementary examination of the muscular activity. It is relevant to consider that the TMD and OP attendance services that were analyzed occur concomitantly with the development of scientific researches, justifying such fluctuations. Besides, the surface electromyography, over time, started to be used as a complementary information source and not as a TMD diagnosis method (Table 1).

Table 1. The quantity of procedures records performed during the ten evaluated years

\begin{tabular}{ccccc}
\hline Years & $\begin{array}{c}\text { Low-level } \\
\text { laser } \\
\text { therapy }\end{array}$ & Physiotherapy & $\begin{array}{c}\text { Surface } \\
\text { electromyography } \\
\text { examinations }\end{array}$ & $\begin{array}{c}\text { Speech } \\
\text { therapy }\end{array}$ \\
\hline 2006 & 111 & 111 & 118 & 174 \\
2007 & 276 & 278 & 20 & 79 \\
2008 & 108 & 108 & 5 & 222 \\
2009 & 164 & 166 & 93 & 373 \\
2010 & 219 & 221 & 55 & 368 \\
2011 & 106 & 106 & 8 & 82 \\
2012 & 118 & 118 & 18 & 159 \\
2013 & 442 & 484 & 63 & 531 \\
2014 & 266 & 294 & 89 & 470 \\
2015 & 192 & 194 & 67 & 502 \\
2016 & 162 & 192 & 84 & 327 \\
\hline
\end{tabular}

\section{DISCUSSION}

The TMJ Occlusion and Disorders Service exists for more than 25 years at FORP/USP, and over time the scientific development ended up shaping its characteristics. Even before its formalized existence, there was the concern of diagnosing the pains, the biomechanical and functional alterations of patients referred to the occlusion area so that a treatment could be planned to include their complaints. Due to its own historical trajectory as a dental discipline, the occlusion perception that people used to have about the TMD treatment envisioned providing ideal and possible biomechanics of the stomatognathic system for each case. Dental occlusion and the TMJ were considered as the key players in the "healing"2-4 scenario and the orofacial myofunctional rehabilitation as a stability factor of the stomatognathic system? In the performed retrospective analysis, the total number of attended patients increased over time. The systematization of the computerized registries is accredited to this variation, especially as of 2012. The number of patients' absences in consultations follows the same line of reasoning. There is a false impression that patients were more absent in the long run, but this number was actually higher over the last years due to the greater consistency of registrations. And the number of discharges has also increased for the same reason. But the number of referrals to other disciplines has diminished. The interpretation carried out is that the attendance demand has been a lot more directed by the Primary Care services; therefore, there is less need for rerouting to other specialties, and the referrals end up limited to the cases with combined treatment needs in other areas of health care.

Regarding the treatment modalities, the increase in the number of installations of the occlusion splints was also attributed to the systemization of these computerized records of procedures and attendances. The rise in the number of self-handling guidance to TMD and OP patients was seen as real, because they started to be employed more consistently as an effective treatment technique as of 2012, with validity and effectiveness expressed in literature ${ }^{10,11}$.

Moura et al. ${ }^{6}$ performed a retrospective analysis of medical histories of patients treated in a TMD service from a Brazilian public university, and they obtained similar results. The most adopted treatments were the occlusal splint $(27.6 \%)$ and counseling $(22.6 \%)$. Likewise, the authors have found a low number of referrals to other TMD-related disciplines, supporting this study's results that found a reduction of these referrals over the years. This fact may indicate higher assertiveness and knowledge of the Primary Care dental surgeons in diagnosing, referring these patients to TMD and OP specialized centers, generating a lower number of improper referrals.

Some patients seek the service looking for an occlusion splint because they were oriented by the dentist of the Primary Care that this would be the carried-out treatment, or due to media information. A study performed in 2015 investigated the knowledge on the diagnosis and handling of TMD in a relevant dentists' sample according to years after their graduation. The authors found that for the majority of the researched people, the occlusion splint is the most well-established treatment option within dentistry and the most used one, with the additional handling options for the TMD being less mentioned. Besides, the longer the graduated time, the action of these dentists ${ }^{8}$ was more towards occlusion practices Such information is compatible with the results of this study since they highlight that despite the new TMD control possibilities that have been appearing in the dental area, the occlusion splint is a therapy still widely used. However, the self-handling guidance and control of triggering and worsening factors have been increasing over time (Figure 2), highlighting a broader understanding regarding pathophysiology, comorbidities and emotional factors associated with the TMD.

According to Michelotti et at. ${ }^{12}$, in a short period, the guidance regarding the pain condition and self-handling are more effective than the occlusion splint, delivered without any guidance, in the reduction of spontaneous muscular pain in TMD patients. Therefore, literature already signs that only using the inter-occlusion devices do not seem to be the option with the best value for money.

The multidisciplinary acting involving physiotherapy and speech therapy, albeit depending on the annual fluctuations concerning the difficulties related to the demand of professionals acting in the OP area, is of great importance and shows a growth tendency over the last 10 years, which highlights a change in the dental practice and in the models of chronic pain care. The dentist, a professional historically graduated for an isolated and secluded 
acting in his practice, finds, in the TMD and the OP, an area in which is impossible to work in a technical and isolated manner, since these conditions extrapolate the oral territory and require clinical reasoning along with professionals from other areas.

This multidisciplinary experience has been strengthening year after year in this service. The demand of patients with TMD to correlated areas such as physiotherapy and speech therapy happens mainly due to the referrals and requests from the dentists involved, who realize during the clinical evaluation the necessity of handling the functional aspects that may be related to the TMD and $\mathrm{OP}^{13,14}$ medical condition. The convergence of triggers to the trigeminal nucleus and the functional overload, whether it is in the stomatognathic system or the cervical region, justify the importance of these professionals in the attendance team ${ }^{15}$.

\section{CONCLUSION}

The collection of data related to the analyzed TMD and OP service demonstrated, over the ten years, an increase in the number of attendances, besides the growing appreciation of practices targeted at pain education, self-handling guidance, and multidisciplinary acting. Among the therapeutic possibilities, the occlusal splint has shown itself as a still quite utilized option in dentistry. These results, added to the increase in the number of discharges and decrease of referrals to other specialties, highlight a higher assertiveness in the service attendance flow. Both the referral of the patients by the Primary Care and the diagnostic and treatment of the analyzed attendance showed an increase in the resolution capacity and efficiency throughout the years.

\section{REFERENCES}

1. Ohrbach R, Dworkin SF. The evolution of TMD diagnosis: past, present, future. J Dent Res. 2016;95(10):1093-101.

2. Mackie A, Lyons $\mathrm{K}$. The role of occlusion in temporomandibular disorders--a review of the literature. N Z Dent J. 2008;104(2):54-9.

3. Okeson JP. Evolution of occlusion and temporomandibular disorder in orthodontics: past, present, and future. Am J Orthod Dentofacial Orthop. 2015;147(5 Suppl):S216-23.

4. Ramfjord SP, Ash MM. Reflections on the Michigan occlusal splint. J Oral Rehabil. 1994;21(5):491-500.

5. Gil-Martínez A, Paris-Alemany A, López-de-Uralde-Villanueva I, La Touche R. Man agement of pain in patients with temporomandibular disorder (TMD): challenges and solutions. J Pain Res. 2018;11:571-87.

6. Moura WP, Silva PL, Lemos GA, Bonan PR, Montenegro RV, Batista AU. Retrospective review of patients referred to a temporomandibular dysfunction care setting of a Brazilian public university. Rev Dor. 2017;18(2):128-34.

7. Ommerborn MA, Kollmann C, Handschel J, Depprich RA, Lang H, Raab WH. A survey on German dentists regarding the management of craniomandibular disorders. Clin Oral Investig. 2010;14(2):137-44.

8. Reissmann DR, Behn A, Schierz O, List T, Heydecke G. Impact of dentists' years since graduation on management of temporomandibular disorders. Clin Oral Investig. 2015;19(9):2327-36.

9. Felício CM, Silva MA, Nunes LJ. Síndrome dor-disfunçăo miofascial: uma abordagem fonoaudiológica. Odontol Mod. 1991;18(5):26-8.

10. Greene CS. Managing the care of patients with temporomandibular disorders: a new guideline for care. J Am Dent Assoc. 2010;141(9):1086-8.

11. Durham J, Al-Baghdadi M, Baad-Hansen L, Breckons M, Goulet JP, Lobbezoo F, et al. Self-management programmes in temporomandibular disorders: results from an international Delphi process. J Oral Rehabil. 2016;43(12):929-36.

12. Michelotti A, Iodice G, Vollaro S, Steenks MH, Farella M. Evaluation of the shortterm effectiveness of education versus an occlusal splint for the treatment of myofascial pain of the jaw muscles. J Am Dent Assoc. 2012;143(1):47-53.

13. Donnarumma MD, Muzilli CA, Ferreira C, Nemr K. Disfunçóes temporomandibulares: sinais, sintomas e abordagem multidisciplinar. Rev CEFAC. 2010;12(5):788-94.

14. Ferreira CL, Machado BC, Borges CG, Rodrigues Da Silva MA, Sforza C, et al. Impaired orofacial motor functions on chronic temporomandibular disorders. J Electromyogr Kinesiol. 2014;24(4):565-71.

15. De Leeuw R. Dor Orofacial - Guia de Avaliaçấo, Diagnóstico e Tratamento. $4^{\mathrm{a}}$ ed. São Paulo: Quintessence; 2010.315p. 